\title{
PROFIL BIOAUTOGRAFI DAN UJI PENANGKAP RADIKAL 2,2-DIFENIL-1-PIKRIHIDRAZIL OLEH EKSTRAK ETANOL DAUN BINAHONG (Anredera scandens (L.) Moq.) DAN FRAKSI-FRAKSINYA
}

\author{
P. O. Samirana*, D. A. Swastini, A. A. G. R. Y. Putra, I. P. W. Kusuma, \\ N. P. A. Y. Pratiwi, V. A. Setiawan \\ Program Studi Farmasi FMIPA Universitas Udayana, Bukit Jimbaran, Bali \\ *Email: oka_samirana@unud.com
}

\begin{abstract}
ABSTRAK
Radikal bebas merupakan atom atau molekul yang mempunyai satu atau lebih elektron yang tidak berpasangan dan bersifat sangat reaktif. Antioksidan memiliki kemampuan menginaktifasi berkembangnya reaksi oksidasi berlebihan. Daun binahong (Anredera scandens (L.) Moq.) merupakan salah satu bagian tanaman yang mengandung senyawa flavonoid dan tanin yang secara ilmiah memiliki aktivitas sebagai antioksidan. Penelitian ini bertujuan untuk mengetahui profil bioautografi dan menguji aktivitas antioksidan dari ektrak etanol daun Anredera scandens (L.) Moq. dengan metode penangkap radikal 2,2-difenil-1-pikrilhidrazil. Rendemen yang diperoleh dari proses ekstraksi dalam penelitian ini adalah 19,22\%, fraksinasi menghasilkan Rendemen fraksi n-heksan sebesar 11,22\% (11,224 gram), fraksi kloroform sebesar 14,68\% (14,684 gram), fraksi etil asetat diperoleh rendemen 3,09\% (3,094 gram), dan fraksi n-butanol diperoleh rendemen sebesar $23,90 \%$ (23,904 gram). Hasil uji profil bioautografi yang menggunakan metode KLT-Densitometri didapat bahwa ekstrak etanol, fraksi kloroform dan fraksi etil asetat memiliki aktivitas penangkap radikal DPPH. Pada penetapan kadar flavonoid total, didapat fraksi etil asetat mengandung kadar flavonoid total yang lebih tinggi dibandingkan dengan fraksi-fraksi lainnya. Pada fraksi etil asetat, didapat kadar flavonoid total yang tinggi dan nilai IC50 yang rendah, sedangkan pada fraksi n-heksan dihasilkan kadar flavonoid yang rendah dan nilai IC50 yang tinggi.
\end{abstract}

Kata kunci: antioksidan, daun binahong, radikal bebas, flavonoid, IC50.

\begin{abstract}
Free radicals are atoms or molecules that have one or more unpaired electrons and are highly reactive. Antioxidants can inhibit the excessive oxidation reaction. The leaves of binahong (Anredera scandens (L.) Moq.) are one part of plants which contain flavonoid compounds and tannins that have scientific activity as antioxidants. This study aims to determine the bioautographic profile and to test the antioxidant activity of the ethanol extract of the leaves of Anredera scandens (L.) Moq. useing 2.2-diphenyl-1-pikrilhidrazil radical capture method. The extraction process produced $19.22 \%$ yield, $14.68 \%$ (14.684 grams) chloroform fraction, $11.22 \%$ (11.224 grams) n-hexane fraction, 3.09\% (3.094 grams) ethyl acetate fraction, and 23.90\% (23.904 grams) n-butanol fraction. The results of bioautographic profile test using KLT densitometry method proved that ethanol extract, chloroform fraction and ethyl acetate fraction have DPPH radical capture activities. The determination of total flavonoid content found that ethyl acetate fraction contained higher total flavonoids than other fractions. In the ethyl acetate fraction, high total flavonoid level and low $\mathrm{IC}_{50}$ values were obtained, while the n-hexane fraction had low flavonoid level and high $\mathrm{IC}_{50}$ values.
\end{abstract}

Keywords: antioxidants, binahong leaves, free radicals, flavonoids, IC50.

\section{PENDAHULUAN}

Radikal bebas merupakan atom atau molekul yang mempunyai satu ataupun lebih elektron yang tidak berpasangan dan memiliki sifat sangat reaktif (Fessenden and Fessenden, 1986). Antioksidan memiliki kemampuan menginaktivasi berkembangnya reaksi substansi dengan cara mencegah terbentuknya radikal atau dengan mengikat radikal bebas dan mendonorkan elektron untuk menstabilkan radikal bebas (Vaya dan Aviram, 2001; Kumalaningsih, 2006).

Salah satu jenis tanaman yang digunakan dalam pengobatan yaitu daun Binahong 
(Anredera scandens (L.) Moq.). Secara empiris binahong digunakan untuk menyembuhkan berbagai gangguan kesehatan dan jenis penyakit seperti mempercepat pemulihan pasca operasi maupun melahirkan, berbagai luka dalam, melancarkan peredaran darah dan tekanan darah, mencegah terjadinya stroke, maag dan asam urat, menurunkan panas tinggi, dan diabetes (Manoi, 2009). Penelitian yang dilakukan Samirana dkk, (2016) melaporkan bahwa ekstrak etanol Anredera scandens (L.) Moq. Terbukti menyembuhan luka eksisi yang secara tidak langsung disebabkan oleh adanya antioksidan dari senyawa flavonoid. Senyawa yang diketahui memiliki aktivitas antioksidan pada umumnya adalah senyawa dengan golongan fenol dan polifenol. Salah satu contohnya adalah flavonoid (Van Acker et al., 1996). Flavonoid berfungsi sebagai antiradikal bebas melalui penekanan radikal bebas atau Reactive Oxygen Species (ROS), baik dengan cara menghambat enzim atau pengkelatan ion logam yang berhubungan dengan produksi radikal bebas melalui peredaman radikal bebas (Subarnas, 2001).

Penelitian yang dilakukan oleh Djamil dkk., (2012) melaporkan aktivitas antioksidan dari ekstrak metanol daun A. cordifolia (Ten.) Steenis merupakan golongan antioksidan kuat dilihat dari nilai $\mathrm{IC}_{50}$ sebesar 53, $11 \mu \mathrm{g} / \mathrm{mL}$. Namun dalam aplikasinya pada sediaan farmasi, pelarut metanol tidak dipergunakan terkait dengan toksisitasnya. Asam formiat yang terbentuk dari metanol menghambat aktivitas dari oksidase sitokrom yang mengakibatkan degeneratif saraf mata yang mengakibatkan kebutaan dan juga menyebabkan asidosis metabolik hingga kematian. Sehingga digunakan etanol sebagai pelarut sediaan karena lebih aman dibandingkan dengan metanol (Skrzydlewska et al., 1999).

Untuk mengetahui potensi suatu senyawa sebagai antioksidan digunakan metode penangkap radikal DPPH (2,2-difenil-1pikrihidrazil). Metode DPPH dipilih berdasarkan pada keuntungan yang dimiliki yaitu murah, cepat, sederhana serta reagen yang dipergunakan mudah dipreparasi (Antolovich $e t$ al., 2001). Metode penentuan aktivitas antioksidan terbagi menjadi dua yaitu secara kualitatif dan kuantitatif. Dimana secara kualitatif digunakan profil KLT bioautografi yang merupakan uji kualitatif senyawa metabolit sekunder dengan penyemprotan menggunakan pereaksi pewarna yaitu DPPH (2,2-difenil-1-pikrilhidrazil). Metode kuantitatif yang digunakan adalah metode spektrofotometri dengan pereaksi DPPH.

Tujuan utama dari penelitian ini adalah untuk mengetahui aktivitas antioksidan dari ekstrak etanol daun binahong beserta fraksi nheksan, fraksi kloroform, fraksi etil asetat, dan fraksi n-butanol dengan metode penangkapan radikal DPPH secara kualitatif dan kuantitatif.

\section{MATERI DAN METODE}

\section{Bahan}

Bahan yang digunakan pada penelitian ini adalah Bahan tanaman yang digunakan adalah daun binahong (Anredera scandens (L.) Moq.) Pelarut yang digunakan untuk ekstraksi daun binahong (Anredera scandens (L.) Moq.) adalah etanol $70 \%$ yang berderajat teknis. Bahan yang digunakan untuk uji fitokimia adalah ekstrak etanol daun A. scandens, plat silika gel $\mathrm{GF}_{254}$ (Merck), bahan serbuk DPPH (Sigma), bahan pelarut klorofom P (Merck), metanol P (Merck), n-heksan P (Merck), etil asetat P(Merck), dan nbutanol P (Merck) yang seluruhnya berderajat pro analis. Selain itu, digunakan juga bahan yang berderajat teknis yaitu aquadest. Bahan yang digunakan untuk uji aktivitas antioksidan adalah ekstrak etanol daun A. scandens serbuk DPPH dan vitamin C (Sigma), bahan pelarut metanol (Merck) yang berderajat pro analisis.

\section{Peralatan}

Peralatan yang digunakan yaitu toples kaca, blender, mortir, stamper, sudip, cawan porselen, kertas saring, sendok tanduk, alat gelas, pinset, timbangan analitik $\left(\mathrm{AND}^{\circledR}\right)$, Rotary evaporator $\left(\right.$ Eyela $\left.^{\circledR}\right)$, pipet kapiler, bejana pengembang (CAMAG), lampu UV CAMAG.

\section{Cara Kerja \\ Penyiapan bahan}

Daun Binahong (Anredera scandens (L.) Moq.) dikumpulkan dan dicuci kemudin disortasi. Daun kemudian dikeringkan dengan cara diangin-anginkan dan dihindarkan dari paparan sinar matahari secara langsung. Sampel yang telah kering diserbukkan dengan menggunakan blender. Serbuk yang dihasilkan dibungkus dan disimpan pada tempat kering. 
Ekstraksi Daun
Scandens (L.) Moq.)
Serbuk daun
scandens (L.) Moq.) kering ditimbang.sebanyak
500 gram, kemudian dimaserasi dengan pelarut
$\begin{array}{lll}\text { etanol } 70 \% & \text { sebanyak } 5 \text { liter selama } \pm 24 \\ \text { jam dengan } & \text { dilakukan pengadukan. Maserat } \\ \text { kemudian } & & \text { disaring. }\end{array}$ Residu dimaserasi kembali dengan cara yang sama dengan 2,5 liter etanol $70 \%$ pengulangan sebanyak 2 kali. Filtrat yang dihasilkan ditampung menjadi satu diendapkan semalam dan diuapkan dengan menggunakan alat vaccum rotary evaporator dan dioven pada suhu $40^{\circ} \mathrm{C}$, sampai diperoleh ekstrak kental

\section{Fraksinasi ekstrak etanol daun Anredera scandens (L.) Moq.}

Ekstrak etanol daun A. scandens yang sudah didapat dilarutkan dengan etanol:air (4:1) dan diaduk hingga semua ekstrak larut. Selanjutnya campuran dimasukkan ke dalam corong pisah dan dilakukan fraksinasi dengan pelarut $n$-heksan, kloroform, etil asetat, dan nbutanol. Fraksi yang didapat kemudian diuapkan menggunakan alat rotary evaporator $68^{\circ} \mathrm{C}$, hingga diperoleh fraksi kering.

\section{Uji Fitokimia Ekstrak Etanol Daun Binahong (Anredera scandens (L.) Moq.) dan Fraksi- Fraksinya}

Pemeriksaan steroid dan triterpenoid dilakukan dengan reaksi LiebermannBurchard. Sebanyak 2 mL larutan uji diuapkan dalam cawan penguap. Residu dilarutkan dengan $0,5 \mathrm{~mL}$ kloroform, kemudian ditambahkan $0,5 \mathrm{~mL}$ asam asetat anhidrat. Selanjutnya ditambahkan $2 \mathrm{~mL}$ asam sulfat pekat melalui dinding tabung. Terbentuk cincin kecoklatan atau violet pada perbatasan larutan menunjukkan adanya triterpenoid, sedangkan bila muncul cincin biru kehijauan menunjukkan adanya sterol.

Pemeriksaan saponin diawali dengan 10 $\mathrm{mL}$ larutan uji dalam tabung reaksi dikocok vertical selama 10 detik dan dibiarkan selama 10 detik. Terbentuknya busa setinggi $1-10 \mathrm{~cm}$ yang stabil selama tidak kurang dari 10 menit, menunjukkan adanya saponin. Dengan penambahan 1 tetes $\mathrm{HCl} 2 \mathrm{~N}$, busa tidak hilang (Depkes RI, 1989).

Pemeriksaan tanin dilakukan dengan 1 $\mathrm{mL}$ larutan ekstrak uji direaksikan dengan larutan besi (III) klorida 10\%, jika terjadi warna biru tua atau hitam kehijauan menunjukkan adanya tanin. Pemeriksaan flavonoid dengan reaksi kimia dengan prosedur. Sebanyak $1 \mathrm{~mL}$ larutan ekstrak uji diuapkan hingga kering, sisanya dibasahkan dengan aseton $\mathrm{P}$, ditambahkan sedikit serbuk halus asam borat $\mathrm{P}$ dan serbuk halus asam oksalat P, dipanaskan hati-hati di atas tangas air dan dihindari pemanasan berlebih. Sisa yang diperoleh dicampur dengan $10 \mathrm{~mL}$ eter P. Diamati dengan sinar UV 366 nm; larutan berfluoresensi kuning intensif, menunjukkan adanya flavonoid.

Pemeriksaan flavonoid dilakukan dengan membuat Larutan uji dengan cara melarutkan 10 mg ekstrak dan fraksi-fraksi daun $A$. scandens (L.) Moq. dalam $5 \mathrm{~mL}$ metanol. Larutan ekstrak uji selanjutnya ditotolkan sebanyak $6 \mu \mathrm{L}$ menggunakan pipet kapiler pada lempengan KLT silica gel $\mathrm{GF}_{254}$ yang telah dicuci dan diaktifkan. Lempengan dielusi di dalam bejana pengembang yang telah dijenuhkan dengan sistem pelarut n-butanol:asam asetat:aquadest (4:1:5) hingga tanda batas. Setelah elusi, lempengan dikeringkan dalam oven pada suhu $60^{\circ} \mathrm{C}$ selama 5 menit. Bercak yang diperoleh dideteksi di bawah sinar UV $366 \mathrm{~nm}$ baik sebelum maupun sesudah diuapi ammonia. Dilihat dan diidentifikasi fluoresensi yang terlihat (Markham, 1988).

Uji Aktivitas Antioksidan Ekstrak Etanol Daun Binahong (Anredera scandens (L.) Moq.) dan Fraksi-Fraksinya dengan Spektrofotometri

Kontrol positif yang digunakan adalah vitamin $\mathrm{C}$, dibuat dalam konsentrasi $1 \mathrm{mg} / \mathrm{mL}$ dalam metanol, kemudian diencerkan dengan metanol hingga diperoleh konsentrasi $1 ; 2 ; 4 ; 8$; dan $16 \mu \mathrm{g} / \mathrm{mL}$, Larutan DPPH disiapkan sebagai radikal bebas dalam penelitian ini. Ditimbang $15,8 \mathrm{mg}$ serbuk DPPH dan dilarutkan dengan metanol dalam labu ukur $100 \mathrm{~mL}$, ditentukan panjang gelombang maksimal DPPH dengan memipet larutan DPPH 0,4 mM sebanyak $1 \mathrm{~mL}$ dan ditambahkan $4 \mathrm{~mL}$ metanol, kemudian campuran divorteks dan dibiarkan selama 30 menit.

Campuran diukur absorbansinya menggunakan spektrofotometer UV-Vis pada rentang panjang gelombang $450-550 \mathrm{~nm}$. Diamati nilai panjang gelombang maksimal dengan melihat nilai absorbansi tertinggi pada satu titik panjang gelombang (Samirana Dkk, 2017). Pengukuran aktivitas penangapan radikal bebas DPPH diawali 
dengan sejumlah sampel uji ditambahkan dengan $1 \mathrm{~mL}$ DPPH $0,4 \mathrm{mM}$ dan 3,95 metanol. Campuran tersebut divorteks dan dibiarkan selama 30 menit. Campuran lalu diukur absorbansinya pada panjang gelombang $515 \mathrm{~nm}$ dengan menggunakan blanko metanol. Pengukuran absorbansi juga dilakukan terhadap kontrol yang terdiri dari $1 \mathrm{~mL}$ DPPH dan $4 \mathrm{~mL}$ metanol (Samirana et al, 2017)

\section{HASIL DAN PEMBAHASAN}

\section{Ekstraksi Daun Binahong (Anredera scandens} (L.) Moq.)

Proses maserasi dilakukan dengan merendam $1 \mathrm{~kg}$ serbuk daun A. scandens (L.) Moq. dalam 5 Liter pelarut etanol $70 \%$. Rendemen yang diperoleh dari proses ekstraksi dalam penelitian ini adalah $19,22 \%$ dengan berat ekstrak yang diperoleh 192,21 gram dari 1000 gram serbuk simplisia daun A. scandens (L.) Moq. yang diekstraksi.

\section{Fraksinasi Ektrak Etanol Daun Binahong (Anredera scandens (L.) Moq.)}

Rendemen ekstrak diambil sebanyak 100 gram kemudian dilarutkan dengan campuran etanol:air (4:1) hingga terlarut. Larutan tersebut kemudian difraksinasi dengan metode ekstrasi cair-cair menggunakan corong pisah berukuran $250 \mathrm{~mL}$. Proses partisi metode ekstraksi caircair berlangsung secara berulang-ulang sebanyak 3 kali.

Pelarut yang digunakan dalam proses fraksinasi terdiri pelarut $n$-heksan (1:1) dengan volume $n$-heksan dipergunakan masing-masing sebanyak $100 \mathrm{~mL}$ dan air $30 \mathrm{~mL}$. Proses partisi kedua digunakan pelarut kloroform (1:1) digunakan masing-masing $30 \mathrm{~mL}$. Proses partisi ketiga digunakan pelarut etil asetat (1:1) digunakan masing-masing $30 \mathrm{~mL}$. Proses partisi keempat digunakan pelarut n-butanol (1:1) digunakan masing-masing $30 \mathrm{~mL}$. Dilakukan partisi pula digunakan cara yang sama dengan pelarut etil asetat (1:1) hingga diperoleh fraksi etil asetat. Hasil fraksinasi selanjutnya diuapkan pelarutnya didalam oven pada suhu $40^{\circ} \mathrm{C}$.
Tabel 1. Hasil Fraksinasi Ekstrak Etanol Daun Binahong (Anredera scandens (L.) Moq.)

\begin{tabular}{lcc}
\hline Sampel & Berat $(\mathrm{g})$ & Rendemen $(\%)$ \\
\hline N-Heksan & 11,224 & 11,22 \\
Kloroform & 14,684 & 14,68 \\
Etil Asetat & 3,094 & 3,09 \\
N-Butanol & 23,904 & 23,90 \\
\hline
\end{tabular}

Hasil fraksinasi tersebut menghasilkan beberapa rendemen fraksi terdiri dari fraksi nheksan sebesar $11,22 \%$ (11,224 gram), fraksi kloroform sebesar 14,68\% (14,684 gram), fraksi etil asetat diperoleh rendemen 3,09\% (3,094 gram), dan fraksi n-butanol diperoleh rendemen sebesar 23,90\% (23,904 gram). Fraksi n-butanol merupakan fraksi dengan rendemen terbanyak dikarenakan pelarut $n$-butanol memiliki tingkat kepolaran semipolar menuju polar sehingga banyak golongan senyawa yang terfraksi ke pelarut ini (Samirana dkk., 2017).

\section{Hasil Uji Fitokimia Ekstrak Etanol Daun Binahong (Anredera scandens (L.) Moq.) Dan Fraksi-Fraksinya}

Uji fitokimia yang dilakukan yaitu pada kandungan flavonoid, saponin, triterpenoid dan tanin. Uji fitokimia ini dilakukan berdasarkan hasil uji fitokimia pada penelitian Sebelumnya yang menyatakan Bahwa golongan kandungan kimia yang terdapat dalam ekstrak etanol daun binahong (Anredera scandens (L.) Moq.) terdiri dari flavonoid, saponin, triterpenoid dan tanin (Samirana, 2010; Karismawan, 2013; Samirana dkk, 2017). Hasil uji fitokimia ekstrak etanol daun binahong (Anredera scandens (L.) Moq.) dan fraksi-fraksinya ditunjukkan pada tabel 2.

Tabel 2. Hasil Uji Fitokimia Ekstrak Etanol Daun Binahong (Anredera scandens (L.) Moq.) dan Fraksi-Fraksinya

\begin{tabular}{lccccc} 
Uji Fitokimia & $\begin{array}{r}\text { Ekstrak } \\
\text { Etanol }\end{array}$ & $\begin{array}{c}\text { Fraksi N- } \\
\text { Heksan }\end{array}$ & $\begin{array}{c}\text { Fraksi } \\
\text { Kloroform }\end{array}$ & $\begin{array}{c}\text { Fraksi Etil } \\
\text { Asetat }\end{array}$ & $\begin{array}{c}\text { Fraksi N- } \\
\text { Butanol }\end{array}$ \\
\hline Flavonoid & + & - & + & + & + \\
Saponin & + & + & + & + & + \\
Triterpenoid & + & + & + & + & + \\
Tanin & + & + & + & + & + \\
\hline
\end{tabular}


Ekstrak etanol daun binahong (Anredera scandens (L.) Moq.), fraksi kloroform, fraksi etil asetat dan fraksi n-butanol terdapat senyawa golongan flavonoid, saponin, triterpenoid dan tanin. Namun pada fraksi nheksan tidak ditemukan adanya senyawa golongan flavonoid. Adanya golongan senyawa yang terdapat pada ekstrak dan setiap fraksi dikarenakan tingkat kepolaran dan kelarutannya, senyawa yang bersifat polar akan mudah larut dalam pelarut polar, sedangkan senyawa non polar akan mudah larut dalam pelarut non polar (like dissolves like). Pelarut yang digunakan yaitu etanol yang bersifat polar dengan indeks polaritas 5,2 sehingga dapat menarik keempat golongan kandungan kimia tersebut (Snyder, 1997).

\section{Hasil Penetapan Kadar Flavonoid Total Ekstrak Etanol Daun Binahong (Anredera scandens (L.) Moq.) Dan Fraksi-Fraksinya}

Kadar flavonoid total ekstrak etanol daun $A$. scandens (L.) Moq. diperoleh sebesar 9,25\%b/b $\pm 0,09$ yang dihitung sebagai rutin, dan data perhitungan kadar flavonoid total ekstrak dapat dilihat pada tabel 3. Hasil penetapan kadar flavonoid total menunjukkan bahwa fraksi etil asetat mengandung kadar flavonoid total yang lebih tinggi dibandingkan dengan fraksi-fraksi lainnya.

Tabel 3. Kandungan Flavonoid Total Sampel

\begin{tabular}{|c|c|c|c|c|}
\hline \multirow[b]{2}{*}{ Sampel } & \multicolumn{3}{|c|}{ Kandungan Flavonoid Total (\%b/b ER) } & \multirow[t]{3}{*}{$\%$ ER rata- } \\
\hline & & & & \\
\hline & 1 & 2 & 3 & \\
\hline Ekstrak Etanol & 9,2 & 9,35 & 9,2 & $9,25 \pm 0,09$ \\
\hline Fraksi N-Heksana & 2,3 & 2,02 & 2,58 & $2,3 \pm 0,28$ \\
\hline Fraksi Kloroform & 4,41 & 4,27 & 4,7 & $4,46 \pm 0,22$ \\
\hline Fraksi N-Butanol & 5,26 & 5,54 & 4,84 & $5,21 \pm 0,35$ \\
\hline Fraksi Etil Asetat & 10,06 & 10,5 & 10,62 & $10,39 \pm 0,29$ \\
\hline
\end{tabular}

Hasil Uji Profil Bioautografi KLT Ekstrak Etanol Daun Binahong (Anredera scandens (L.) Moq.) dan Fraksi-Fraksinya

Hasil profil bioautografi sebelum disemprot dengan DPPH 0,2\% menunjukkan pada ekstrak etanol, fraksi etil asetat, dan fraksi kloroform terdapat bercak yang hampir sama pada Rf 0,73. Bercak-bercak pada Rf 0,73 sebelum diberikan pereaksi penampak bercak menunjukkan warna kuning pudar di bawah sinar tampak, berwarna lembayung gelap di bawah sinar UV $254 \mathrm{~nm}$, serta berfluoresensi warna lembayung gelap di bawah sinar UV $366 \mathrm{~nm}$. Selanjutnya KLT diidentifikasi dengan disemprot menggunakan larutan DPPH 0,2\%.

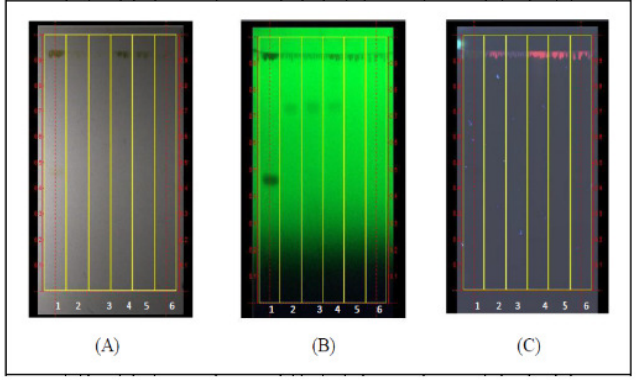

Gambar 1. Hasil Profil KLT Bioautografi Ekstrak Etanol Daun Binahong (Anredera scandens (L.) Moq.) Pada Sinar Tampak (A), Sinar UV $254 \mathrm{~nm}$ (B) dan Sinar UV $366 \mathrm{~nm}$ (C) Sebelum Disemprot dengan Larutan DPPH 0,2\%.

Keterangan: 1. Standar Rutin; 2. Ekstrak Etanol; 3. Fraksi Etil Asetat; 4. Fraksi Kloroform; 5. Fraksi NButanol; 6. Fraksi N-Heksan.

Hasil kromatogram setelah disemprot dengan larutan DPPH 0,2\% menunjukkan pada ekstrak etanol, fraksi etil asetat, dan fraksi kloroform $(\operatorname{Rf} 0,73)$ memiliki warna bercak yang sama yaitu warna kuning dibawah sinar tampak dengan latar berwarna ungu, warna lembayung gelap di bawah sinar UV $254 \mathrm{~nm}$, dan di bawah sinar UV $366 \mathrm{~nm}$ berfluoresensi lembayung gelap.

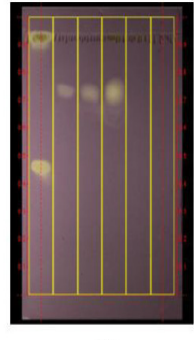

(A)

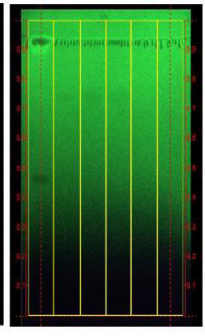

(B)

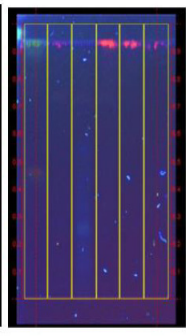

Gambar 2. Hasil Profil KLT Bioautografi Ekstrak Etanol Daun Binahong (Anredera scandens (L.) Moq.) Pada Sinar Tampak (A), Sinar UV $254 \mathrm{~nm}$ (B) dan Sinar UV $366 \mathrm{~nm}$ (C) Setelah Disemprot dengan Larutan DPPH $0,2 \%$.

Keterangan: 1. Standar Rutin; 2. Ekstrak Etanol; 3. Fraksi Etil Asetat; 4. Fraksi Kloroform; 5. Fraksi NButanol; 6. Fraksi N-Heksan.

Hasil uji profil bioautografi didapat bahwa ekstrak etanol, fraksi kloroform dan fraksi etil asetat memiliki aktivitas penangkap radikal DPPH yang ditandai dengan bercak berwarna kuning pada latar belakang berwarna ungu di $\mathrm{Rf} 0,73$ dengan 
menggunakan fase diam silika gel 60 GF254 dan fase gerak campuran pelarut etil asetat: asam formiat : asam asetat : air (100:11:1 1:26) v/v. Menurut penelitian Andhini (2018), pada metode KLT dengan menggunakan fase diam silika gel GF254 dan fase gerak menggunakan campuran pelarut etil asetat : asam formiat : asam asetat : air (100:11:11:26) v/v diperoleh hasil pada nilai Rf 0,71 adalah senyawa flavonoid. Pada penelitian ini digunakan fase diam dan fase gerak yang sama yaitu campuran pelarut etil asetat : asam formiat : asam asetat : air (100:11:11:26) v/v menghasilkan bercak dengan nilai Rf 0,73 yang mempunyai aktivitas antioksidan yang diduga merupakan golongan senyawa flavonoid.

\section{Hasil Uji Aktivitas Antioksidan Ekstrak Etanol Daun Binahong (Anredera scandens (L.) Moq.) dan Fraksi-Fraksinya dengan Spektrofotometer}

Hasil dari uji penangkap radikal DPPH didapat dari hubungan antara kadar ekstrak etanol beserta fraksi-fraksinya dengan aktivitas penangkap radikal DPPH yang digambarkan pada persamaan regresi linier dengan parameter IC50. Prinsip dari metode uji aktivitas antioksidan ini adalah pengukuran aktivitas antioksidan secara kuantitatif yaitu dengan pengukuran penangkapan radikal DPPH oleh suatu Senyawa yang mempunyai aktivitas antioksidan dengan menggunakan spektrofotometri UV-Vis sehingga dengan demikian akan diketahui nilai aktivitas peredaman radikal bebas Yang dinyatakan dengan nilai IC50 (Inhibitor Concentration) (Molyneux, 2004).

Nilai IC50 didefinisikan sebagai besarnya konsentrasi senyawa uji Yang dapat meredam radikal bebas sebanyak $50 \%$. Semakin kecil nilai IC50 maka aktivitas peredaman radikal bebas Semakin tinggi. Metode ini juga didasarkan atas pengukuran kemampuan antioksidan untuk menekan atau menghambat radikal DPPH. Kemampuan ini dapat dievaluasi dengan resonansi spin elektron atau dengan mengukur penurunan absorbansinya yang diamati dengan spektrofotometer pada panjang gelombang sekitar $515 \mathrm{~nm}$ setelah direaksikan dengan senyawa uji (Prior et al., 2005) Prinsip kerja Dari pengukuran ini adalah adanya radikal bebas stabil yaitu DPPH yang dicampurkan dengan senyawa antioksidan yang memiliki kemampuan mendonorkan hydrogen, sehingga radikal bebas dapat Diredam (Ridho, 2013).

Tabel 4. Hubungan antara Konsentrasi Ekstrak Etanol $70 \%$ dengan Aktivitas penangkapan radikal bebas DPPH

\begin{tabular}{ccc}
\hline $\begin{array}{c}\text { Konsentrasi } \\
\text { Sampel }(\mu \mathrm{g} / \mathrm{mL})\end{array}$ & $\begin{array}{c}\text { Aktivitas } \\
\text { Antioksidan }(\%)\end{array}$ & $\begin{array}{c}\text { Persamaan Garis Regresi } \\
\text { Linier }\end{array}$ \\
\hline 5 & 20,12 & \\
10 & 25,63 & $\mathrm{y}=0,3089 \mathrm{x}+22.107$ \\
20 & 30,78 & $\mathrm{r} \quad=0,9938$ \\
40 & 35,81 & $\mathrm{IC} 50=90,3 \mu \mathrm{g} / \mathrm{mL}$ \\
80 & 46,47 & \\
160 & 71,14 & \\
\hline
\end{tabular}

Pada tabel 4, didapat persamaan regresi linier $\mathrm{y}=0,3089 \mathrm{x}+22,107$ dan memiliki aktivitas penangkap radikal DPPH dengan nilai IC50 sebesar 90,3 $\mu \mathrm{g} / \mathrm{mL}$. Hasil IC50 ekstrak etanol tersebut dikategorikan sebagai antioksidan kuat dengan nilai IC50 yang terdapat pada rentang 50-100 $\mu \mathrm{g} / \mathrm{mL}$ (Putri dan Nurul, 2015).

Tabel 5. Hubungan antara Konsentrasi Fraksi NHeksan dengan Aktivitas penangkapan radikal bebas DPPH

\begin{tabular}{ccl}
\hline $\begin{array}{c}\text { Konsentrasi } \\
\text { Sampel }(\mu \mathrm{g} / \mathrm{mL})\end{array}$ & $\begin{array}{c}\text { Aktivitas } \\
\text { Antioksidan }(\%)\end{array}$ & $\begin{array}{c}\text { Persamaan Garis Regresi } \\
\text { Linier }\end{array}$ \\
\hline 5 & 10,66 & \\
10 & 13,17 & $\mathrm{y}=0,1634 \mathrm{x}+11,201$ \\
20 & 14,85 & $\mathrm{r} \quad=0,9963$ \\
40 & 17,96 & $\mathrm{IC}_{50}=237,45 \mu \mathrm{g} / \mathrm{mL}$ \\
80 & 25,27 & \\
160 & 36,77 & \\
\hline
\end{tabular}

Pada tabel 5, didapat persamaan regresi linier $\mathrm{y}=0,1634 \mathrm{x}+11,201$ dan memiliki aktivitas penangkap radikal DPPH dengan nilai IC50 sebesar 237,45 $\mu \mathrm{g} / \mathrm{mL}$. Hasil IC50 fraksi n-heksan tersebut dikategorikan sebagai antioksidan sedang dengan nilai IC50 yang terdapat pada rentang $100-250 \mu \mathrm{g} / \mathrm{mL}$ (Putri dan Nurul, 2015).

Tabel 6. Hubungan antara Konsentrasi Fraksi Kloroform dengan Aktivitas Penangkap Radikal Bebas DPP

\begin{tabular}{ccc}
\hline $\begin{array}{c}\text { Konsentrasi } \\
\text { Sampel }(\mu \mathrm{g} / \mathrm{mL})\end{array}$ & $\begin{array}{c}\text { Aktivitas } \\
\text { Antioksidan }(\%)\end{array}$ & $\begin{array}{c}\text { Persamaan Garis Regresi } \\
\text { Linier }\end{array}$ \\
\hline 5 & 10,9 & \\
10 & 16,77 & $\mathrm{y}=0,2616 \mathrm{x}+16,724$ \\
20 & 26,11 & $\mathrm{r} \quad=0,9513$ \\
40 & 32,1 & $\mathrm{IC}_{50}=127,2 \mu \mathrm{g} / \mathrm{mL}$ \\
80 & 41,68 & \\
160 & 55,21 & \\
\hline
\end{tabular}


Pada tabel 6, didapat persamaan regresi linier $\mathrm{y}=0,2616 \mathrm{x}+16,724$ dan memilik aktivitas penangkap radikal DPPH dengan nilai IC50 Sebesar 127,2 $\mu \mathrm{g} / \mathrm{mL}$. Hasil IC50 fraksi kloroform tersebut dikategorikan sebagai antioksidan sedang dengan nilai IC50 yang terdapat pada rentang 100-250 $\mu \mathrm{g} / \mathrm{mL}$ (Putri dan Nurul, 2015).

Tabel 7. Hubungan antara Konsentrasi Fraksi NButanol dengan Aktivitas Penangkap Radikal Bebas DPPH

\begin{tabular}{ccl}
\hline $\begin{array}{c}\text { Konsentrasi } \\
\text { Sampel }(\mu \mathrm{g} / \mathrm{mL})\end{array}$ & $\begin{array}{c}\text { Aktivitas } \\
\text { Antioksidan }(\%)\end{array}$ & $\begin{array}{c}\text { Persamaan Garis Regresi } \\
\text { Linier }\end{array}$ \\
\hline 5 & 13,29 & \\
10 & 19,16 & $\mathrm{y}=0,2287 \mathrm{x}+17,017$ \\
20 & 23,95 & $\mathrm{r} \quad=0,9779$ \\
40 & 28,5 & $\mathrm{IC}_{50}=144,22 \mu \mathrm{g} / \mathrm{mL}$ \\
80 & 37,37 & \\
160 & 51,86 & \\
\hline
\end{tabular}

Pada tabel 7, didapat persamaan regresi linier $\mathrm{y}=0,2287 \mathrm{x}+17,017$ dan memiliki aktivitas penangkap radikal DPPH dengan nilai IC50 sebesar 144,22 $\mu \mathrm{g} / \mathrm{mL}$. Hasil IC50 fraksi n-butanol tersebut dikategorikan sebagai antioksi dan sedang dengan nilai IC50 yang terdapat pada rentang 100-250 $\mu \mathrm{g} / \mathrm{mL}$ (Putri dan Nurul, 2015).

Tabel 8. Hubungan antara Konsentrasi Fraksi Etil Asetat dengan Aktivitas Penangkap Radikal Bebas DPPH

\begin{tabular}{ccc}
\hline $\begin{array}{c}\text { Konsentrasi } \\
\text { Sampel }(\mu \mathrm{g} / \mathrm{mL})\end{array}$ & $\begin{array}{c}\text { Aktivitas } \\
\text { Antioksidan }(\%)\end{array}$ & $\begin{array}{c}\text { Persamaan Garis Regresi } \\
\text { Linier }\end{array}$ \\
\hline 5 & 22,4 & \\
10 & 30,3 & $\mathrm{y}=0,9917 \mathrm{x}+27,038$ \\
20 & 36,17 & $\mathrm{r} \quad=0,9809$ \\
40 & 42,99 & IC $_{50}=69,23 \mu \mathrm{g} / \mathrm{mL}$ \\
80 & 57,49 & \\
160 & 77,37 & \\
\hline
\end{tabular}

Pada tabel 8 , didapat persamaan regresi linier $\mathrm{y}=0,9917 \mathrm{x}+27,038$ dan memiliki aktivitas penangkap radikal DPPH dengan nilai IC50 sebesar $69,23 \mu \mathrm{g} / \mathrm{mL}$. Hasil IC50 fraksi Etil Asetat tersebut dikategorikan sebagai antioksidan kuat dengan nilai IC50 yang terdapat pada rentang 50-100 $\mu \mathrm{g} / \mathrm{mL}$ (Putri dan Nurul, 2015)

Pada penelitian ini digunakan vitamin $\mathrm{C}$ sebagai senyawa pembanding yang sebelumnya telah diketahui sebagai antioksidan alami. Hubungan antara kadar vitamin $\mathrm{C}$ dengan aktivitas penangkapan radikal bebas DPPH digambarkan dalam persamaan regresi linier $\mathrm{y}=$ $5,008 x+11,297$ dengan nilai IC50 sebesar 7,73 $\mu \mathrm{g} / \mathrm{mL}$.
Tabel 9. Hubungan antara Konsentrasi Vitamin C dengan Aktivitas Penangkap Radikal Bebas DPPH

\begin{tabular}{ccc}
\hline $\begin{array}{c}\text { Konsentrasi } \\
\text { Sampel }(\mu g \mathrm{~mL})\end{array}$ & $\begin{array}{c}\text { Aktivitas } \\
\text { Antioksidan (\%) }\end{array}$ & $\begin{array}{c}\text { Persamaan Garis Regresi } \\
\text { I imicr }\end{array}$ \\
\hline 1 & 16,53 & \\
2 & 19,28 & $\mathrm{y}=5,008 \mathrm{x}+11,297$ \\
4 & 30,30 & $\mathrm{r} \quad=0,9959$ \\
8 & 56,05 & $\mathrm{IC}_{50}=7,73 \mu \mathrm{g} / \mathrm{mL}$ \\
16 & 89,58 & \\
\hline
\end{tabular}

Hasil penelitian tersebut menunjukkan bahwa aktivitas penangkap radikal DPPH ekstrak etanol daun Binahong dan fraksifraksinya lebih rendah dibandingkan dengan senyawa pembanding vitamin C. Namun, jika dilihat nilai IC50 dari ekstrak etanol dan fraksi etil asetat daun binahong (Anredera scandens (L.) Moq.), didapat kekuatan aktivitas antioksidannya digolongkan ke antioksidan kuat.

Pada pengujian skrining fitokimia, didapat bahwa ekstrak etanol, dan fraksi-fraksinya memiliki hasil positif pada setiap golongan senyawa yang diuji, kecuali pada fraksi nheksan yang memiliki hasil negatif pada golongan senyawa flavonoid.

Penetapan kadar flavonoid total, didapat fraksi etil asetat mengandung kadar flavonoi $\mathrm{d}$ total yang lebih tinggi dibandingkan dengan fraksi-fraksi lainnya. Hasil uji profil bioautografi didapat bahwa ekstrak etanol, fraksi kloroform dan fraksi etil asetat memiliki aktivita s penangkap radikal DPPH yang ditandai dengan bercak berwarna kuning pada latar belakang berwarna ungu di $\quad$ Rf 0,73 dengan menggunakan fase diam lempeng KLT silika gel 60 GF254 dan fase gerak campuran pelarut etil asetat : asam formiat : asam asetat : air (100:11:11:26) v/v. Hasil profil bioautografi yang didapat memiliki kemiripan pada penelitian yang dilakukan oleh Andhini (2018) bahwa metode KLT yang menggunakan fase diam lempeng KLT silika gel 60 GF254 dan fase gerak campuran pelarut etil asetat : asam formiat : asam asetat : air (100:11:11:26) v/v menghasilkan bercak yang diduga mengandung flavonoid berada di Rf 0,71. Sehingga, dapat dikatakan bahwa yang bertanggungjawab terhadap aktivitas antioksidan adalah senyawa flavonoid. Hubungan antara senyawa flavonoid dengan aktivitas antioksidan ditampilkan pada Gambar 3. 


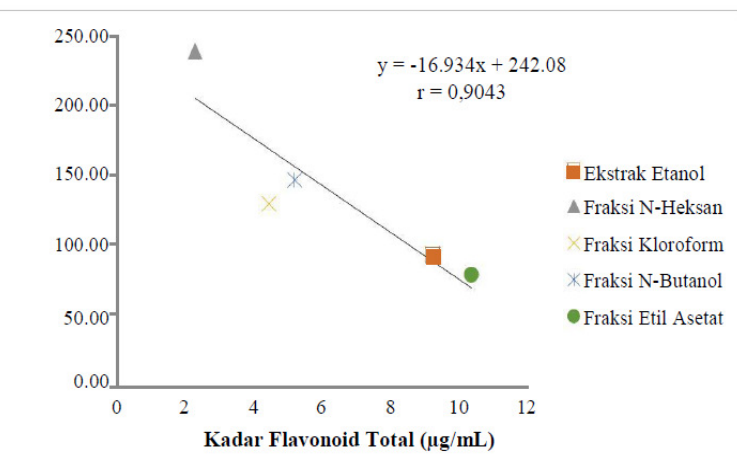

Gambar 3. Kurva Hubungan Antara Kandungan Flavonoid Total dan Nilai $1 C_{50}$

Hubungan antara kandungan flavonoid total dengan nilai IC50 ekstrak etanol dan fraksi-fraksinya digambarkan dengan persamaan regresi $\mathrm{y}=-16,934 \mathrm{x}+242,08$ dan memiliki koefisien korelasi (r) sebesar 0,9043, yang memiliki makna bahwa kandungan flavonoid total dengan nilai IC50 ekstrak etanol dan fraksifraksinya memiliki hubungan yang sangat kuat. Semakin besar kandungan flavonoid total dari ekstrak etanol daun A. scandens beserta fraksifraksinya, maka nilai IC50 nya akan semakin kecil. Pada fraksi etil asetat, didapat kadar flavonoid total yang tinggi dan nilai IC50 yang rendah, sedangkan pada fraksi nheksan dihasilkan kadar flavonoid yang rendah dan nilai IC50 yang tinggi.

\section{SIMPULAN DAN SARAN}

\section{Simpulan}

Profil bioautografi ekstrak etanol daun $A$. scandens yang berperan sebagai penangkap radikal 2,2-difenil-1-pikrilhidrazil adalah pada Rf 0,73 di ekstrak etanol, fraksi kloroform, dan fraksi etil asetat daun Anredera scandens setelah disemprot dengan DPPH $0,2 \%$ menunjukkan

aktivitas antioksidan yang ditandai dengan adanya bercak berwarna kuning dengan latar belakang ungu.

\section{Saran}

Diperlukan penelitian lebih lanjut untuk mengetahui mekanisme antioksidan dari ekstrak daun binahong (Anredera scandens (L.) Moq.).

\section{UCAPAN TERIMAKASIH}

Ucapan terimakasih penulis sampaikan kepada semua pihak yang telah membantu dan mendukung dalam terlaksananya penelitian ini.

\section{DAFTAR PUSTAKA}

Antolovich, M., Paul D. P., Emilioa P., Suzanne M. and Kevin R. 2001. Methods for Testing Antioxidant Activity. The Analyst. Vol. 127: 183-198

Departemen Kesehatan Republik Indonesia. 1989. Materia Medika Indonesia Jilid $V$. Direktorat Pengawasan Obat dan Makanan. Jakarta

Djamil, R., Wahyudi. P.S., Wahono,S. dan Hanafi. 2012. Antioxidant Activity of Flavonoid From Anredera Cordifolia (Ten) steenis Leaves, Journal of Pharmacy.

Fessenden, R. J. dan Fessenden, J. S. 1986. Kimia Organik. Edisi Ketiga. Jakarta: Erlangga

Karismawan, P. N. 2013. Profil Kandungan Kimia dan Uji Aktivitas Antiluka Bakar Ekstrak Etanol Daun Binahong (Anredera Scandens (L.) Moq.) Pada Tikus Jantan Galur Sprague Dawley (Skripsi),. Universitas Udayana. Denpasar

Kumalaningsih, S. 2006. Antioksidan Alami Penangkal Radikal Bebas, Sumber manfaat, Cara penyediaan, dan Pengolahan. Trubus Agrisana. Surabaya

Manoi, F. 2009. Binahong sebagai Obat. Warta Penelitian dan Pengembangan Tanaman Industri. Vol. 15(1): 3-4.

Markham, K. R. 1988. Cara Mengidentifikasi Flavonoid. Bandung: Penerbit ITB.

Molyneux, P. 2004. The Use of The Stable Free Radical Diphenylpicrylhidrazil (DPPH) for Estimating Antioxidant Activity.J. Sci. Technol. Vol. 26(2): 211-219.

Prabantini, D. 2010. A to $Z$ Makanan Pendamping Asi. Edisi I. Yogyakarta: ANDI. 
Prior, R. L, Wu, X., Schaich, K. 2005. Standardized Methods for the Determination of Antioxidant Capacity and Phenolics in Foods and Dietary Supplements. Journal of Agric. And Food Chemistry. Vol. 53(10): 4290-4302.

Putri, A. A. S. dan Nurul H. 2015. Uji Aktivitas Antioksidan Senyawa Fenolik Ekstrak Metanol Kulit Batang Tumbuhan Nyiri Batu (Xylocarpus moluccensis). UNESA Journal of Chemistry. Vol. 4(1): 1-6.

Ridho, E.A. 2013. Uji Aktivitas Antioksida Ekstrak Metanol Buah Bakum (Cayratia trifolia) dengan Metode DPPH. Skripsi. Universitas Tanjungpura. Pontianak

Samirana, P. O., D. A. Swastini, I. D. G. P. Y. Subartha, dan Ariadi, K. A. 2016. Uji Aktivitas Penyembuhan Luka Ekstrak Etanol Daun Binahong (Anredera scadens (L.) Moq.) pada Tikus Jantan Galur Wistar. Jurnal Farmasi Udayana. 5(2): 19-23.

Samirana, P. O., D. A. Swastini., I. P. R. Ardinanta., I. P. S. D. Suarka. 2017. Penentuan Profil Kandungan Kimia Ekstrak Etanol Daun Binahong (Anredera Scandens (L.) Moq.). Jurnal Farmasi Udayana. 6(1): 24-26.

Samirana, P. O., Swastini., D. A., Satriani, N. W. 2017. Pengaruh Pemberian Ekstrak Etanol 70\% Daun Binahong (Anredera Scandens (L.) Moq.) Terhadap Makroskopik Dan Biokimia Ginjal Mencit Jantan Galur Balb/C. Jurnal Farmasi Udayana. 6(2): 29-30.

Samirana, P. O., Taradipta, I. D. M. R., Leliqia, N. P. E. 2016. Penentuan Profil Bioautografi Dan Aktivitas Antioksidan Ekstrak Etanol Daun Bidara (Ziziphus Mauritiana Auct. Non Lamk.) Dengan Metode Penangkapan Radikal Dpph. Jurnal Farmasi Udayana. 6(2): 19-20.
Samirana, P.O., Susidarti, R.A., and Rohman, A. 2017. Isolation and 2,2'-diphenyl-1picrylhydrazyl radicalscavenging activity of active compound from Jujube tree (Zizyphus mauritiana Auct. non Lamk.). International Journal Of Food Properties. Vol. 20(S2): 1524-1525.

Skrzydlewska, E., Roszkowska A., and Moniuszko-Jakoiuk J. 1999. A Comparison of Methanol and Ethanol Effects on the Activity and Distribution of Lysososmal Proteases. Polish Journal of Environmental Studies. Vol. 8(4): 251257.

Snyder C. R., Kirkland, J. J. and Glajach J. L. 1997. Practical HPLC Method Development. 2th ed. Lnc. 722-723

Subarnas A. 2001. Komponen Aktif Antioksidan Dalam Bahan Alam, Seminar Nasional dan Lokakarya. Pemahaman Konsep Radikal Bebas dan Peranan Antioksidan dalam Meningkatkan Kesehatan Menuju Indonesia Sehat 2010. Pusat Penelitian Kesehatan. Lembaga Penelitian Universitas Padjajaran. Bandung.

Van Acker, S.A., van Den Berg, D.J., Tromp, M.N., Griffioen, D.H.,Van Bennekom, W.P., van der Vijgh, W.J. and Bast A. 1996. Structural aspects of antioxidant activity of flavanoids. Free Radic. Biol. Med. 20(3): 331342.

Vaya, J., dan Aviram, M. 2001. Nutritional Antioxidants: Mechanisms of Action, Analyses of Activities and Medical Applications. Curr. Med. Chem.-Imm, Endoc. and Metab. Agents, 1(1). 